\title{
Chlamydia pneumoniae okozta infektív endocarditis májtranszplantációt követően
}

\author{
P. Szabó Réka dr. ${ }^{1}$ - Kertész Attila dr. ${ }^{2}$ \\ Szerafin Tamás dr. ${ }^{3}$. Fehérvári Imre dr. ${ }^{5}$ - Zsom Lajos dr. ${ }^{4}$ \\ Balla József dr. ${ }^{1}$ - Nemes Balázs dr. ${ }^{4}$ \\ Debreceni Egyetem, Általános Orvostudományi Kar, Klinikai Központ, \\ ${ }^{1}$ Belgyógyászati Intézet, Nephrológiai Tanszék, FMC-Debrecen, ${ }^{2}$ Kardiológiai Intézet, \\ ${ }^{3}$ Kardiológiai Intézet, Szívsebészeti Tanszék, \\ ${ }^{4}$ Sebészeti Intézet, Transzplantációs Tanszék, Debrecen \\ ${ }^{5}$ Semmelweis Egyetem, Általános Orvostudományi Kar, Transzplantációs és Sebészeti Klinika, Budapest
}

\begin{abstract}
Az infektív endocarditis a szervtranszplantált betegek körében aluldiagnosztizált kórkép. A kórokozók spektruma különbözik az átlagpopulációt érintőtől. A szerzők az 58 éves nőbetegben atípusos kórokozó által okozott, atípusos megjelenésű infektív endocarditis eredményes kezeléséről számolnak be. A betegnél alkoholos májcirrhosis talaján kialakult májelégtelenség miatt 2000. februárban májátültetést végeztek. Egy évvel a májátültetést követően krónikus hepatitis B-vírus-fertőzést állapítottak meg, és a beteg antivirális kezelésben részesült. Kalcineurintoxicitás miatt veseelégtelenség alakult ki, ezt követően a beteg 2007 júliusában vesepótló kezelésre szorult. 2013 novemberében rövid ideig tartó afázia jelentkezett. A transoesophagealis echokardiográfia az aortabillentyưn vegetációt talált, a mágneses rezonanciás vizsgálat agyi embolisatiót mutatott ki. A laboratóriumi vizsgálatok enyhén emelkedett C-reaktív protein- és normális prokalcitoninszinteket igazoltak, vérképében leukopenia volt látható. Kezdeti antibiotikus terápiaként naponta $2 \mathrm{~g}$ ceftiraxont és $60 \mathrm{mg}$ gentamycint iv. alkalmaztak a dialízisek után. A hemokultúravizsgálatok negatívak voltak, a szerológiai vizsgálat Chlamydia pneumoniae-fertőzést igazolt. Moxifloxacinnal kiegészített kezelést követően a neurológiai tünetei visszatértek, ezért mútétre került sor (koronarográfiát követően valvulotomia és coronariabypass-mútét). A beteg állapota a mútét után javult, a neurológiai tünetek nem ismétlődtek.
\end{abstract}

Orv. Hetil., 2015, 156(22), 896-900.

Kulcsszavak: infektív endocarditis, májtranszplantáció, Chlamydia pneumoniae

\section{Infective endocarditis caused by Chlamydia pneumoniae after liver transplantation. Case report}

The incidence of infective endocarditis is underestimated in solid organ transplant recipients. The spectrum of pathogens is different from the general population. The authors report the successful treatment of a 58-year-old woman with infective endocarditis caused by atypical microorganism and presented with atypical manifestations. Past history of the patient included alcoholic liver cirrhosis and cadaver liver transplantation in February 2000. One year after liver transplantation hepatitis B virus infection was diagnosed and treated with antiviral agents. In July 2007 hemodialysis was started due to progressive chronic kidney disease caused by calcineurin toxicity. In November 2013 the patient presented with transient aphasia. Transesophageal echocardiography revealed vegetation in the aortic valve and brain embolization was identified on magnetic resonance images. Initial treatment consisted of a 4-week regimen with ceftriaxone ( $2 \mathrm{~g}$ daily) and gentamycin ( $60 \mathrm{mg}$ after hemodialysis). Blood cultures were all negative while serol- 
ogy revealed high titre of antibodies against Chlamydia pneumoniae. Moxifloxacin was added as an anti-chlamydial agent, but neurologic symptoms returned. After coronarography, valvular surgery and coronary artery bypass surgery were performed which resulted in full clinical recovery of the patient.

Keywords: infective endocarditis, liver transplantation, Chlamydia pneumoniae

P. Szabó, R., Kertész, A., Szerafin, T., Fehérvári, I., Zsom, L., Balla, J., Nemes, B. [Infective endocarditis caused by Chlamydia pneumoniae after liver transplantation. Case report]. Orv. Hetil., 2015, 156(22), 896-900.

(Beérkezett: 2015. február 12.; elfogadva: 2015. március 26.)

\section{Rövidítések}

$\mathrm{IE}=$ infektív endocarditis; $\mathrm{CMV}=$ cytomegalovirus; $\mathrm{TTE}=$ transthoracalis echokardiográfia

A fertőzéses endocarditis (IE) a szívüreg endothelialis felszínén megjelenő mikrobás fertőzés, amely fibrinből, vérlemezkéből, mikrobák telepeiből és gyulladásos sejtekből álló felrakódás, vegetáció kialakulásához vezet. Gyakorisága az átlagpopulációban 6/100 000 lakos évente [1]. Az IE mintegy 20 éve változatlanul kedvezőtlen prognózisú $[2,3,4,5,6,7,8,9,10]$. Utóbbi oka részben a diagnosztikus késés, részben az inadekvát kezelés. Az IE incidenciája országonként különböző az eltérő diagnosztikus kritériumoknak megfelelően. Hazai felmérésről nem áll rendelkezésre adat. A nemzetközi adatok alapján incidenciája 2-12/100 000 lakos/év, de 70 éven felülieknél 24/100 000/év, kábítószer-élvezőknél pedig 100/100 000/év körül van [11].

Kevés adat ismert a szervátültetettek körében ezen entitás incidenciájáról. Nincsenek irányelvek a szervátültetettek körében e kórkép diagnosztikájáról és kezeléséről. Ezen betegcsoportban igen magas mortalitással kell számolnunk. Az átlagpopuláció kockázati faktorai a következők: rossz szájhigiénia, iv. kábítószer-élvezet, hemodialízis, tartós kanülviselés, diabetes, múbillentyú. A szervátültetettek körében a bacteriaemiával járó beavatkozások, mint például a bronchoszkópia, gastrointestinalis endoszkópia, májbiopszia és az immunszuppresszió jelentik a legfontosabb hajlamosító tényezőket $[3,12]$.

A patogén kórokozók az átlagpopulációban a következők: alfa-hemolizáló Streptococcusok, Streptococcus bovis, Staphylococcus aureus, Enterococcus spp., HACEKcsoport (Haemophilus spp., Actinobacillus, Cardiobacterium, Eikenella, Kingella), Gram-negatív pálcák (mint például a Salmonella), koaguláznegatív Staphylococcus és gombák. A kórokozók gyakoriságát korábbi közlemények foglalják össze $[2,3,4,5,6,7,8,9,10]$. A natív billentyüt érintő IE esetében a leggyakoribb mikroorganizmusok a Streptococcusok. S. bovis esetén vastagbélfolyamatra kell gondolni, epe- és húgyúti beavatkozások után elsősorban Enterococcus jön szóba. Koaguláznegatív Staphylococcusok ritkán okoznak a natív billentyün
IE-t, múbillentyưn kialakuló IE esetében azonban jelentős szerepük van $[2,3,4,5,6,7,8,9,10]$. Intravénás kábítószer-élvezők infektív endocarditisét elsősorban S. aureus okozza, de Pseudomonas és Candida is előfordul. Az esetek körülbelül 10\%-ában nem tenyészik ki kórokozó a hemokultúrából [11].

Hemodializált betegek körében gyakoribb a negatív tenyésztéssel járó úgynevezett „culture negative” endocarditis $[12,13,14]$. A klinikailag IE-nek gyanítható esetek akár 20\%-ában a szokványosan elvégzett vértenyésztések negatívak. Ezek mögött az előzetes antibiotikus kezelés vagy a következő kórokozók állhatnak: Brucella, Bartonella, Legionella, Mycobacterium, Nocardia, gomba, Coxiella burnetii és Chlamydia. Az etiológia tisztázása speciális tenyésztéseket (például a szokványos hemokultúra helyett líziscentrifugálás) és egyes esetekben (Bartonella, Brucella, Legionella, Coxiella, Chlamydia) szerológiai vizsgálatokat $[3,12]$, sőt újabban PCR-módszereket is igényel [1]. A szervátültetettek körében a három leggyakoribb kórokozó: Staphyloccoccus aureus, Aspergillus és Candida [3, 12].

A klasszikus tünetek gyakoriság sorrendjében a következők: láz, újonnan kialakult szívzörej, petechiák, körömbevérzések, Osler-csomók és Janeway-laesiók. Neurológiai tünetek közül az emboliás stroke fokális neurológiai góctünettel, intracerebralis vérzés, többszörös microabscessusok. További tünetek lehetnek még: új keletú splenomegalia, delírium, tarkókötöttség, afázia, pallor, aritmia, anorexia, fogyás, influenzaszerű tünetek, polymyalgiaszerű tünetek, hányinger, hányás és appendicitist utánzó fájdalom. A diagnózis a módosított Duke-kritériumok alapján klinikai, mikrobiológiai, patológiai és echokardiográfiás vizsgálatokon alapul [13, 14, 15]. Major tenyésztési kritérium: pozitív hemokultúra, típusos mikroorganizmus két mintából, perzisztáló pozitív hemokultúra. Echokardiográfiás kritérium: endocardium érintettségének bizonyítása új keletû regurgitatiós zörej, illetve echokardiográfiás lelet (oszcilláló intracardialis terime a billentyún vagy subvalvularisan, tályog, új múbillentyún paravalvularis szövethiány). Minor kritériumok: hajlamosító szívbetegség, droghasználat, láz, érrendszeri tünetek (major artériás embolia, szeptikus tüdőinfarktus, mycoticus aneurysma, intracranialis vérzés, conjunctivalis vérzés, glomerulonephritis, 
szerológiával igazolt aktív infekció, amely nem meríti ki a major feltételeket. Definitív klinikai diagnózis 2 major kritérium, 1 major és 3 minor vagy 5 minor kritérium meglétekor állapítható meg.

Hemodializáltak körében nagyobb a stroke kockázata. Ishida és munkatársai közölték, hogy dializáltak körében magasabb a cryptogen és kardiális emboliából származó stroke előfordulása, amelynek hátterében krónikusan kalcifikált endocarditis, katéterthrombus és permanens foramen ovale állhat [16].

\section{Esetismertetés}

$\mathrm{Az} 58$ éves nőbeteg alkoholos májcirrhosis talaján kialakult májelégtelenség miatt 1999. májusban májtranszplantációs várólistára került Child $\mathrm{C}$ stádiumban. 2000. februárban cadaver májtranszplantáció történt piggy back szerint. A 0 Rh-pozitív, cytomegalovirus(CMV-) pozitív beteg méretben identikus 0 Rh-pozitív, CMV-pozitív májat kapott. A mútéti idő 6 óra 50 perc, a hideg ischaemiás idő 570 perc volt, a mütét alatt 12 egység vörösvértest-szuszpenzióra volt szükség. Az immunszuppresszív terápia szteroidból, mycofenolát mofetilből és ciklosporinból állt. Annak ellenére, hogy a májátültetés előtt hepatitis $\mathrm{B}$ elleni vakcinációban részesült, hepatitis B-vírus-fertőzése igazolódott egy évvel a transzplantációt követően, és a betegnél lamivudinkezelést kezdtek. Lamivudinrezisztens mutáns (YMDD) megjelenését követően a plazma hepatitis B-vírus-DNStitere 16840 000/ml-t ért el. 2005-ben akut pancreatitis zajlott, emelkedett májenzimszintekkel, majd a krónikus hepatitis B progressziója miatt adeforvirkezelés kezdődött. 2007-ben kalcineurintoxicitás talaján kialakult krónikus vesekárosodás miatt vesepótló kezelés megkezdésére került sor. 2011-ben a hepatitis B-vírusDNS-titer 170000 000/ml volt. Heti kétszer, majd háromszor történt hemodialízis.

2013 novemberében a betegnél rövid ideig tartó afáziás periódus jelentkezett. Az aorta fölött új keletú szisztolés zörej volt hallható, EKG-n sinusrhythmust regisztráltunk. Laboratóriumi vizsgálat enyhén emelkedett C-reaktív protein szintet mutatott ki, a prokalcitoninszint normális volt. A bal karon lévő natív arteriovenosus fisztula lobmentes volt. A transoesophagealis szívultrahang vegetációt mutatott ki az aortabillentyûn (1.ábra), a koponya mágneses rezonanciás vizsgálata szeptikus embolust véleményezett (2. ábra). Az ismételten elvégzett hemokultúra és vizelettenyésztés negatív volt. A szerológiai vizsgálat eredménye a következő volt: Chlamydia pneumoniae IgM ( $\geq 1: 10)$, IgG-pozitív ( $\geq 1: 512)$, Coxiella burnetti IgM-pozitív. A betegnél körömbevérzések jelentkeztek. Nőgyógyászati góc nem igazolódott, a fogászaton 2 fog eltávolítására került sor. Naponta $2 \mathrm{~g}$ ceftiraxon- iv. és a dialízisek után $60 \mathrm{mg}$ iv. rifampinkezelést alkalmaztunk, majd a szerológiai lelet birtokában a gyógyszereket moxifloxacinnal egészítettük ki. A terápia ellenére ismét neurológiai tünetek jelentkez-

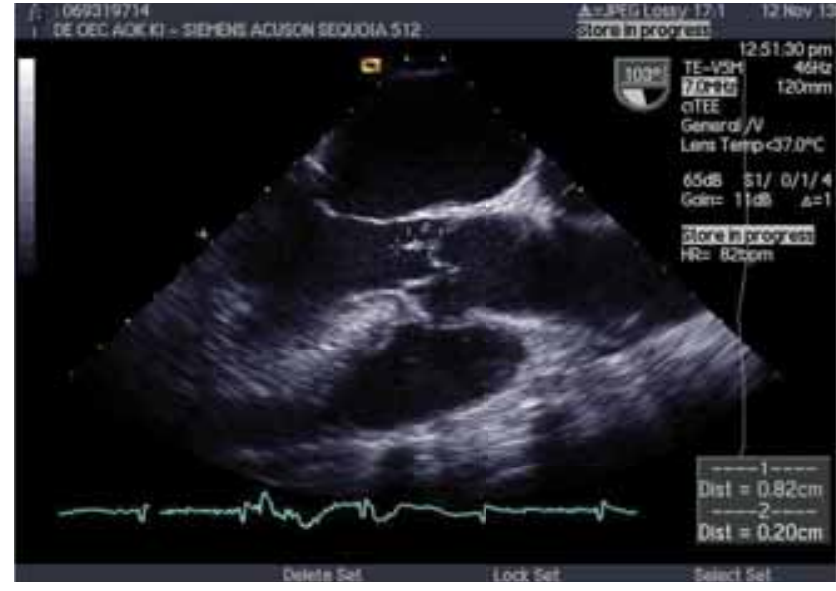

\begin{tabular}{l|l} 
l. ábra & Transoesophagealis echón vegetáció az aortabillentyún
\end{tabular}

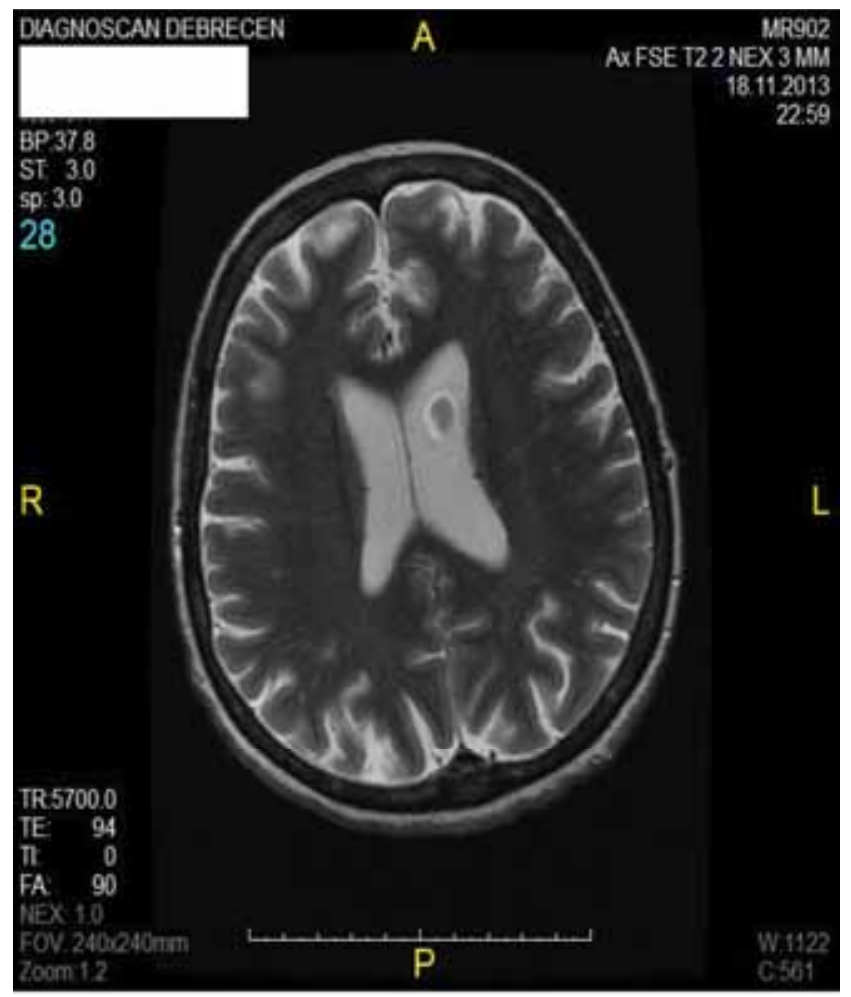

\begin{tabular}{l|l} 
2. ábra & Koponya-MRI. 3 mm-nél kisebb gócok láthatók
\end{tabular}

tek, két alkalommal átmeneti beszédzavar alakult ki. Kontroll-echokardiográfia változatlan méretú vegetációt mutatott ki. Carotis-Doppler-vizsgálat a jobb carotis interna occlusióját, a bal oldali carotis interna 30\%-os és a bal oldali carotis externa $80 \%$-os szúkületét észlelte. Neurológiai vélemény alapján carotisintervenciót nem tartottak szükségesnek. Valvulotomia jött szóba az antibiotikum-kezelés mellett visszatérő neurológiai tünetek és a változatlan echokardiográfiás kép miatt. 50 év feletti betegek esetében a billentyümütét előtt javasolt koronarográfia a LAD és az RCA szignifikáns szúkületét igazolta. Szívsebészeti bemutatáson valvulotomiát és kétágas bypassmütétet indikáltak. A mütét során a vege- 
tációt eltávolították. A mütét óta a beteg jól van, neurológiai tünetei nem ismétlődtek. 2014. szeptemberben a májfunkciós leletek normálisak voltak, a hemoglobin $10,7 \mathrm{~g} / \mathrm{L}$, hematokrit 33\%, szérumkreatinin: $463 \mu \mathrm{mol} / \mathrm{L}$, vérurea 14,3 $\mathrm{mmol} / \mathrm{L}$ volt.

\section{Megbeszélés}

Közleményünkben szervtranszplanált, hemodializált, krónikus hepatitis B-vírus-fertőzésben szenvedő beteg sikeresen kezelt infektív endocarditisét ismertettük. Esetünket azért tartottuk prezentációra érdemesnek, mert az infektív endocarditis hátterében atípusos kórokozó állt, atípusos klinikai manifesztációval. A szervtranszplantáció és uraemia következményeként kialakult többszörösen immunszupprimált állapot ellenére a kezelés sikeres volt és a beteg meggyógyult.

Az IE klinikai diagnózisa gyakran nehéz az aspecifikus tünetek (elhúzódó vagy visszatérő láz, deréktáji fájdalom, fogyás) miatt. A legfontosabb a gyanú korai felvetése. IE gyanúját keltik a következő kombinációk: billentyúhiba és ismeretlen eredetú láz, új regurgitatiós zörej és láz, láz és embolia, múbillentyú és legalább egy hete fennálló láz, illetve ezek bármely további kombinációja (láz közvetlenül a diagnosztikus vagy terápiás beavatkozás után nosocomialis, láz és vascularis jelenségek, láz és multiplex tüdőembólia [jobbszívfél-IE], microhaematuria). Gyakori az anaemia (az esetek 7090\%-ában), a gyorsult süllyedés (az esetek 90\%-ában) és a proteinuria (az esetek 50-65\%-ában). A leukocytosis nem jellemző, az esetek 20-30\%-ában fordul elő. Hat hétnél hosszabb lefolyás esetén gyakori a rheumatoidfaktor-pozitivitás (az esetek 40-50\%-ában) [17, 18, 19, 20].

Major Duke-kritériumot jelentő echokardiográfiás ismérvek a következők: vegetáció, abscessus és periprosztetikus dehiscentia. További strukturális szövődmények közé tartozik a pseudoaneurysma, fenesztráció, fisztula, billentyưruptura és az ínhúrruptura. Definíció szerint a vegetáció a billentyưhöz csatlakozó mobilis echótömeget jelenti. Az atrioventricularis billentyúk pitvari felszínén, az ínhúrokon, az aortabillentyú bármely felszínén, múbillentyưkereten, idegen testen, ritkán a fali endocardiumon helyezkedik el. Az abscessus nem pulzatilis, echómentes vagy echóval kitöltött, esetleg rekeszes paravalvularis üreg, fóleg paraaorticus elhelyezkedésú. A pseudoaneurysma pulzatilis, echómentes, az aorticomitralis kontinuitásban elhelyezkedő üreg, amelynek rupturája fisztulát okozhat, vagy a pericardiumzsákba törhet be és ezzel tamponádot okoz [21, 22, 23]. Fenesztráció: a billentyúszövet folytonossági hiánya [20]. Az IE hemodinamikai következményeit Doppler-echokardiográfiával mutatjuk ki. A billentyüdestrukció következménye az akut regurgitatio, múbillentyú-IE-nél az akut paravalvularis regurgitatio, ritkán fisztulák vagy nagy vegetáció okozta obstrukció (fóleg MBIE-nél). Ezek a következmények balkamra-diszfunkcióhoz, pulmonalis hypertoniához, hemodinamikai katasztrófához vezetnek. A transthoracalis echokardiográfia (TTE) alkalmas a natív billentyún elhelyezkedő IE-vegetációk ábrázolására a korábban ép billentyúkön, a rupturák, továbbá a hemodinamikai következmények kimutatására. A TTE diagnosztikus értéke korlátozott a paravalvularis üregek tekintetében, és nem alkalmas a mübillentyü-IE diagnosztikájára. Az IE leggyakoribb perifériás szövődménye az embolia: balszívfél-endocarditisben 30-40\%ban fordul elő, és az esetek több mint fele stroke formájában jelentkezik. Az emboliaveszély kockázati tényezői közé tartozik a baktérium típusa, a fertőzés aktivitása és a vegetációk morfológiája, lokalizációja. Egy 10 tanulmányt feldolgozó metaanalízis szerint a 10 mm-nél nagyobb vegetáció egyértelmű emboliaveszélyt jelent [24], de a 3 TEE-tanulmány közül csak egy igazolta ezt a tételt [25] natív billentyúkre és mitralis pozícióra korlátozva.

Hemodializáltak körében a negatív tenyésztésű infektív endocarditisnek jó a prognózisa [26]. Olyan esetekben, ahol többszörös hajlamosító tényezőkkel rendelkezik a betegünk, gondoljunk atípusos kórokozókra is! Immunszupprimált állapotú betegnél larváltan jelentkezhetnek a tünetek. Az IE leggyakoribb tünete a láz, de ez immunszupprimált állapotban ritkább. A szívelégtelenség a leggyakoribb szövődmény (az esetek 40-60\%ában), ezt követi az embolisatio (az esetek 20-40\%-ában). Az emboliák fele cerebralis, ezért gyakori az IE első jeleként fellépő stroke láz kíséretében. A hajlamosító tényezők figyelembevételével (agyembolia, időskor, cukorbetegség, hemodialízis, aortalokalizáció), az adekvát mikrobiológiai mintavételi technikával és szerológiai vizsgálattal segíthetjük mindennapi munkánkat, betegeink sikeres kezelését ebben a magas mortalitású betegségben.

Anyagi támogatás: A közlemény megírása anyagi támogatásban nem részesült.

Szerzôi munkamegosztás: P. Sz. R., B. J.: A betegség diagnosztizálása, a beteg gyógyítása. K. A:. Kardiológiai kezelés. Sz. T.: Szívmútét. F. I:. Májtranszplantáció. Zs. L., N. M.: A beteg utógondozása. A cikk végleges változatát valamennyi szerző elolvasta és jóváhagyta.

Érdekeltségek: A szerzőknek nincsenek érdekeltségeik.

\section{Irodalom}

[1] Tulassay, Z. (ed.): Fundamentals of internal medicine. [A belgyógyászat alapjai.] Medicina Könyvkiadó, Budapest, 2011. [Hungarian]

[2] Netzer, R. O., Zollinger, E., Seiler, C., et al.: Infective endocarditis: clinical spectrum and outcome. An analysis of 212 cases. 1980-1995. Heart, 2000, 84(1), 25-30.

[3] Horstkotte, D., Follath, F., Gutschik, E., et al.: Guidelines on Prevention, Diagnosis and Treatment of Infective Endocarditis Executive Summary. The Task Force on Infective Endocarditis of the European Society of Cardiology. Eur. Heart J., 2004, 25(3), $267-276$ 
[4] Lengyel, M.: Infective endocarditis. In: Temesvári, A., Gyenes, G. (eds.): Cardiology 2000. [Infektív endocarditis. In: Temesvári, A., Gyenes, G. (szerk.): Kardiológia, 2000.] Melánia Kiadó, Budapest, 2000. [Hungarian]

[5] Durack, D. T., Lukes, A. S., Bright, D. K., et al.: New criteria for the diagnosis of infective endocarditis: utilization of specific echocardiographic findings. Duke Endocarditis Service. Am. J. Med., 1994, 96(3), 200-209.

[6] Ruttmann, E., Bonatti, H., Legit, C., et al.: Severe endocarditis in transplant recipients - an epidemiologic study. Transpl. Int., 2005, 18(6), 690-696.

[7] Durack, D. T., Approach to diagnosis of infective endocarditis. Clin. Microbiol. Infect., 1998, 4(Suppl. 3), S3-S9.

[8] Gutschik, E.,: Microbiological recommendations for the diagnosis and follow-up of infective endocarditis. Clin. Microbiol. Infect., 1998, 4(Suppl. 3), S10-S16.

[9] Bayer, A. S., Bolger, A. F., Taubert, K. A., et al.: Diagnosis and management of infective endocarditis and its complications. AHA Scientific Statement. Circulation, 1998, 98(25), 2936-2948.

[10] Stamboulian, D., Carbone, E.: Recognition, management and prophylaxis of endocarditis. Drugs, 1997, 54(5), 730-744.

[11] Prendergast, B. D.: Diagnostic criteria and problems in infective endocarditis. Heart, 2004, 90(6), 611-613.

[12] Árvay, A., Lengyel, M.: Incidence and risk factors of prosthetic valve endocarditis. Eur. J. Cardiothorac. Surg., 1988, 2(5), 340346.

[13] DeCastro, S., d'Amati, G., Cartoni, D., et al.: Valvular perforation in left-sided infective endocarditis: a prospective echocardiographic evaluation and clinical outcome. Am. Heart J., 1997, 134(4), 656-664

[14] Tischler, M. D., Vaitkus, P. T.: The ability of vegetation size on echocardiography to predict clinical complications: a metaanalysis. J. Am. Soc. Echocardiogr., 1997, 10(5), 562-568.

[15] Mügge, A., Daniel, W. G., Frank, G., et al.: Echocardiography in infective endocarditis: reassessment of prognostic implications of vegetation size determined by the transthoracic and the transesophageal approach. J. Am. Coll. Cardiol., 1989, 14(3), 631-638.
[16] Ishida, K., Brown, M. G., Weiner, M., et al.: Endocarditis is a com mon stroke mechanism in hemodialysis patients. Stroke, 2014, 45(4), 1164-1166.

[17] Oh, T. E. (ed.): Intensive care manual. Infective endocarditis. 4th ed. Butterworth Heinemann, Hong Kong, 1996.

[18] http://www.uptodate.com/contetns/antimicrobial-therapy-ofnative-valve- endocarditis

[19] Paterson, D. L., Dominguez, E. A., Chang, F. Y.: Infective endocarditis in solid organ transplant recipients. Clin. Infect. Dis., 1998, 26(3), 689-694.

[20] Wu, I. W., Chen, Y. C., Chang, M. Y., et al.: Excellent prognosis of culture negative endocarditis in hemodialysis patients: a case series. Ren. Fail., 2007, 29(6), 767-771.

[21] Lamas, C. C., Eykyn, S. J.: Blood culture negative endocarditis: analysis of 63 cases presenting over 25 years. Heart, 2003, 98(3), 258-262.

[22] Bayer, A. S., Bolger, A. F., Taubert, K. A., et al.: Diagnosis and management of infective endocarditis and its complications. AHA Scientific Statement. Circulation, 1998, 98(25), 29362948

[23] Ali, A. S., Trivedi, V., Lesch, M.: Culture-negative endocarditis - a historical review and 1990s update. Prog. Cardiovasc. Dis., 1994, 37(3), 149-160.

[24] Stamboulian, D., Carbone, E.: Recognition, management and prophylaxis of endocarditis. Drugs, 1997, 54(5), 730-744.

[25] Tingleff, J., Egeblad, H., Gotzsche, G. O., et al.: Perivalvular cavities in endocarditis: abscesses versus pseudoaneurysms? A transesophageal Doppler echocardiographic study in 118 patients with endocarditis. Am. Heart J., 1995, 130(1), 93-100.

[26] Afridi, I., Apostolidou, M. A., Saad, R. M., et al.: Pseudoaneurysms of the mitral-aortic intervalvular fibrosa: dynamic characterization using transesophageal echocardiographic and Doppler techniques. J. Am. Coll. Cardiol., 1995, 25(1), 137-145.

(P. Szabó Réka dr., Debrecen, Nagyerdei krt. 98., 4012 e-mail: rpszabo@belklinika.com) 